\title{
REDUCTION OF FOOD WASTAGE THROUGH DONATION USING ONLINE FOOD MANAGEMENT SYSTEM FOR ORPHANAGE
}

\author{
Pritom Kumer Rajvor \\ Department of Computer Science and Engineering, \\ Shanto-Mariam University of Creative Technology, Dhaka, Bangladesh \\ Md. Shafiqul Islam Shovon \\ Department of Computer Science and Engineering, \\ Shanto-Mariam University of Creative Technology, Dhaka, Bangladesh \\ MiniraAkter \\ Department of Computer Science and Engineering, \\ Shanto-Mariam University of Creative Technology, Dhaka, Bangladesh \\ Farzana Nawrin \\ Department of Computer Science and Engineering, \\ Shanto-Mariam University of Creative Technology, Dhaka, Bangladesh \\ Suraiya Yasmin \\ Department of Computer Science and Information Technology, \\ Bangabandhu Sheikh Mujibur Rahman Agricultural University, Gazipur-1706, Dhaka, Bangladesh
}

\begin{abstract}
Hungers in the world are burning issue now-adays and wastage of food is increasing day by day. Surplus Food for Orphanage (SFO) is an online food management system that manages extra food for starving people who have not enough food to remain alive. The aim of the research is to develop a web-based portal named "Surplus Food for Orphanage" which makes a communication between donor and food seeker. This paper represents a new internet-based website that will be helpful for donating old stuff and extra food to all needy people. In this website the donor can register his/her account. When registration becomes successful, donor can access this website by $\log$ in to their account. Donor will publish their post by enrolling their food item's name, quantity of food that donor want to donate, their contact number and location also. A simple notification is given to the admin. Charity can view the donor/restaurant post by logging in to this website. Then charity can contact to the food donor and collected the surplus food from donor and collected food will be distributed to the disadvantaged people. This system will be helpful to reduce the wastage of food, inspiration for the donor to come forward to donate foods for orphanage easily.
\end{abstract}

Keywords - Donor, Orphanage, Food wastage, Internet, Web portal, Database, Charity, Post.

\section{INTRODUCTION}

Food waste or food loss refers to the food that is spoilt, lost or uneaten. The causes of food loss occur very often because of the mismanagement of producing, processing, and vending of the food [1]. Every year an estimated 1.3 billion [2] of food is wasted globally and one-third of food produced for human consumption [3]. Wastage occurs at all stages of the food supply chain. A huge amount of wastage happens at the time of production in the poor countries whereas a large amount of food (around 100 kilograms) for each person per year is wasted in the consumption period in developed countries [4]. Bangladesh is a highly populated country although it has an emerging economy approximately $49 \%$ of its population is still being lived below the poverty level. Food waste is one of the emerging threats to the food security of the country [5]. In Bangladesh, nearly $5.5 \%$ of the total procured food is being wasted by a person at the time of eating daily [6]. Besides this, a large proportion $(52 \%)$ of food is waste during different occasions like marriage ceremonies, birthday parties, etc [7]. Despite accelerated economic growth and increasing production, food waste will be a concern for the food security 
of the country. To reduce food waste and feed the hungry people, it is important to find a way to collect surplus food from different occasions and donate this to various organizations like orphanages, old age homes, etc. Recently, people donate surplus food material manually by visiting each organization number of times. In India, where food waste is also a big issue, developed some websites and apps like https://www.feedingindia.org[8]and https://www.giveindia.org [9] are trying to reduce food waste and helping people by donating their wasted food for the needy people through their official website where the donor can donate food, funds and also volunteer for various activities. Bangladesh has 'Bidyanondo. The organization' is an innovative organization that is starting "One taka meal" for street children as well as cloth and free academic teaching in Bangladesh [10]. The people who are living in the streets, who have to eat at the same price, have to pay a meal at a price to feed them.

The goal of this website is to reduce food waste and save food for charity, orphanage, and street children. This portal has made the pavement easy as the way of communication between charities and restaurants. This website is a place where the charities and restaurants/donors will have to create an account. The restaurants/donors will donate their surplus food to charities by logging into their account through this website. The root purpose of this website is to collect surplus food and distribute them to charities by creating a bridge between the donors and charities.

\section{LITERATURE SURVEY}

The paper 'Helping Hands' [11], published in 2016, a modern web-based application that provides a platform for donating old attire and rescue food to all starving people/Organizations. It provides facts and information about motivation to come forward with such an application, thereby describing the current donation system and for the betterment of society how the proposed system works. The disadvantage of this project is that there is no control panel available that is, at the end of the month the system doesn't get all the information that how much is donated or received by someone.

The paper 'Beyond food sharing: Supporting food waste reduction With ICTs'[12], published in 2016, present that food security plays a key role in increasing the quality of life of people at all levels of society. The current economic crisis has enhanced the number of people living in conditions of food poverty, especially in developed sites. Despite rising awareness of the significance of reducing waste and handling food surplus, in this domain, the role of ICTs is still not clear and only just documented. This paper presents the use of ICT tools to collect food surplus at various stages of the supply chain and also present the way forward for an integrated set of ICT tools to decrease waste out of producers to houses.
The paper 'Food Wastage Reduction through Donation' [13], published in 2018, this paper describes that a huge amount of food is wasted in marriages, restaurants, college canteens, social functions, and different places. So they present an idea of developing a web-based application through which people will be able to donate their remnant easily without doing any manual work. This web-based portal which has large retail chains and possibly restaurant/NGOs/organizations can donate surplus food using this web portal. Their application can be used only for food donations. For other items like clothes, food grains, books, utensils this application cannot be used.

The paper 'Mobile Application for Excess Food Donation and Analysis' [14], published in 2018, describes that every day 1.3 billion tons of food is wasted and one third consumed are remnant. This application provides information on the amount of food waste and the impact is visualized by using data analysis. They notice the hungry people and minimize food wastage at once. They send alerts to nearby NGOs, Orphanages, and Volunteers to collect the food.

The paper "The Challenges of Establishing Food Donation System" [15], which was published in 2017, describes food donation organizations that have responsibilities to collect food from businesses and individuals, storage it, distribute it to the food banks and finally forward it toward people of community who are starving from particular goods. The main objective of this paper is to address some organizational issues that set in the way of the creation of sustainable food donation system.

\section{EXISTING SYSTEM}

Every year 1.3 billion tons of food is devastated and 1 in every 7 people in the world go to bed hungry. Everyday more than 20,000 children below the age of 5 die from hunger. According to the waste database of Bangladesh, food and vegetable waste embraces approximately $67.75 \%$ of urban solid waste [16]. This food will be become wasted because there are no ways to share food with anyone if they are having much extra food. If they want to donate extra food to any charity or orphanage or starving people they don't have any idea about that. That's why we have developed a website for donating their extra food to charity, orphanage, and street people by which food waste will be reduced in our country.

\section{EXPERIMENT AND RESULT}

The system of this research work was web-based. PHP (Personal Home Page) is a script language and interpreter [17] that is used to develop the website. This is a web-based application developed using zend framework and required an internet connection. It also covered the design of prototype development and its implementation. It is also shown that the use case diagram and project workflow diagram to discuss the 


\section{International Journal of Engineering Applied Sciences and Technology, 2021 \\ Vol. 5, Issue 10, ISSN No. 2455-2143, Pages 37-43 \\ Published Online February 2021 in IJEAST (http://www.ijeast.com)}

proposed method in this work. This website supports an online food donation system using the internet. The website is shown as an effective means of donating thing to various organizations over the internet.

Many restaurants, organizations are willing to donate their surplus food to needy people. Many organizations want to help which is required for them such as clothes, food, money, books, etc., but there is no source available where they can assure their requirements. This web-based portal is developed through which donors can write a post to donate food items and organizations such as a charity that can see the donor's post and also contact the donor through this website. If any people want to donate their extra food, they can do it from this free platform. When donors and food seekers will access this web portal, they must have to be registered by the sign-up option and for this, they need an internet connection. After successful registration, both donor and seeker will be able to access this website.

\section{Usecase diagram (donor, actor, receiver)}

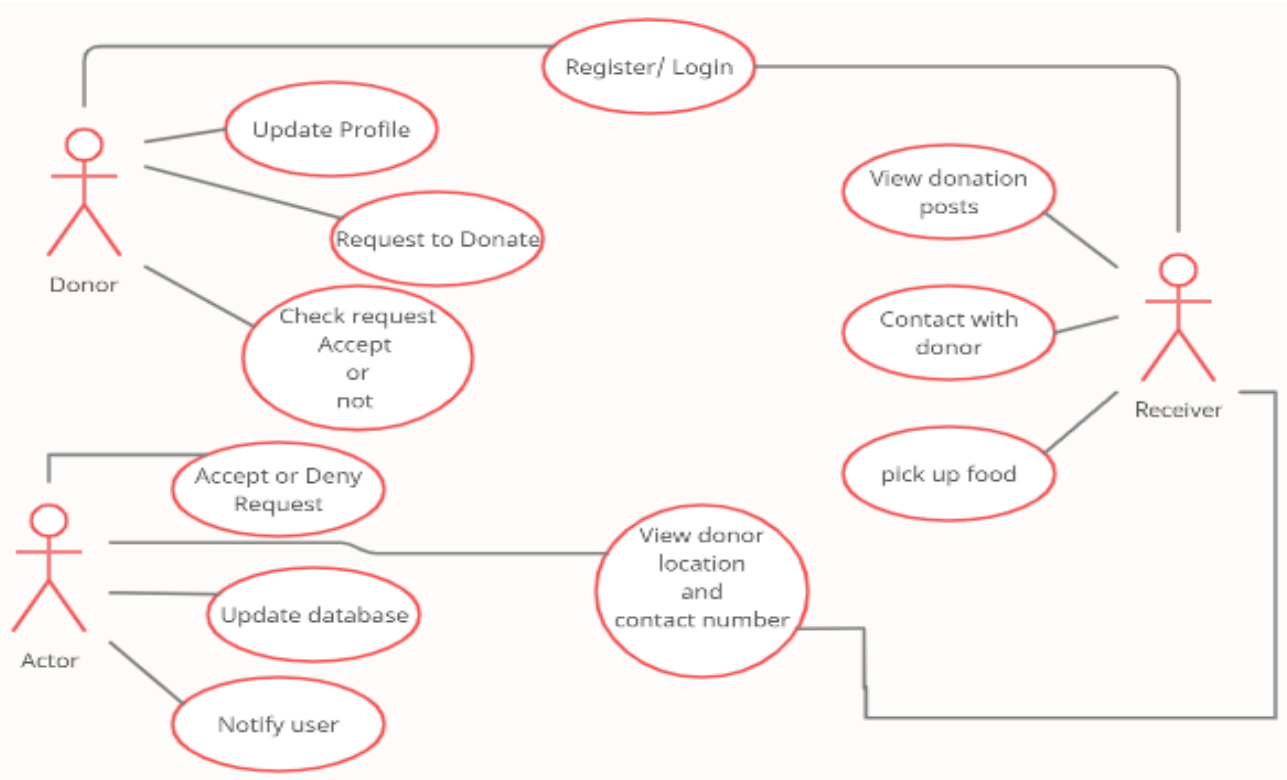

Figure 1: Usecase Diagram

Project Workflow Diagram

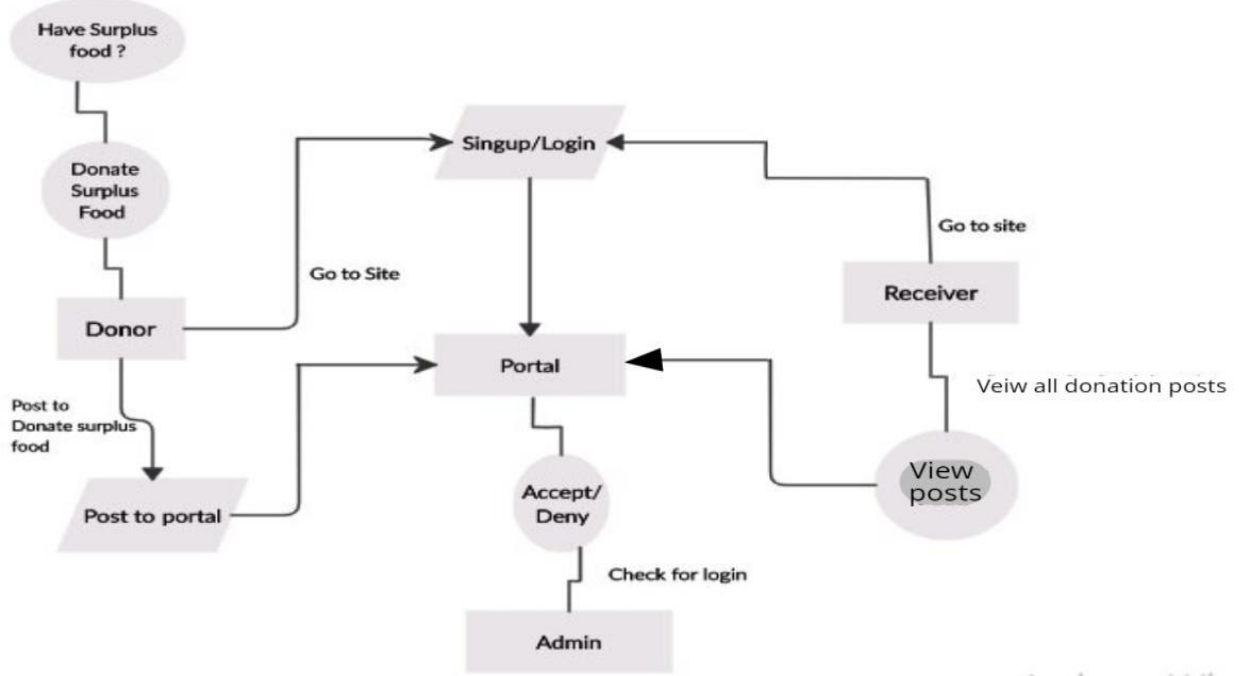

Figure 2: Project Workflow 


\section{International Journal of Engineering Applied Sciences and Technology, 2021 \\ Vol. 5, Issue 10, ISSN No. 2455-2143, Pages 37-43 \\ Published Online February 2021 in IJEAST (http://www.ijeast.com)}

There are 3 actors on this website and they are Admin, Donor and Receiver. According to figure1, the donor has options like Update profile, Request to donate, Check request accept or not, and Signup/login, into the system. After creating an account using sign up, donors can enter into the website with a login option. If a Donor is willing to donate their surplus food, he/she can write the post through the website. If the admin accepts the request, this post will be shown as a published post in the portal to other users (charity). This post will be stored in the database. If the donor wishes, the Donor can update his/her profile for example he can delete the post or edit the post. The donor can check the post whether the request has been accepted or not. The receiver can be organizations/NGOs/Charity who needs food for starving people. Receivers also access this webpage by login option.
When the receiver login to the website he/she view all posts which were posted by the donor. After viewing the post, the receiver will contact the donor if food is needed then the receiver will collect food from a donor distributed to the needy poor people. Admin is a notify user. Admin will remain responsible for approving or denying the entire request considering a donation. When the donor will post for donation then the admin can accept the request. Admin can see the donor's location. All information will be monitored and updated by the admin. This website will be beneficial to fill up the communication gap between charity and food donors. This website will reduce food wastage and also helps to save food as well as it will be able to protect major food waste which is happening in Bangladesh.

Table 01: Elements of the research work

\begin{tabular}{|c|c|}
\hline $\begin{array}{l}\text { Name of the } \\
\text { elements }\end{array}$ & Function \\
\hline Admin & $\begin{array}{l}\text { - Responsible for accepting or denying user's request } \\
\text { - } \quad \text { Notify the users } \\
\text { - Monitor or update all types of information }\end{array}$ \\
\hline Donor & $\begin{array}{l}\text { - } \text { Send request to donate } \\
\text { - } \text { Create post after login } \\
\text { - Get notification from admin whether the post is published or not }\end{array}$ \\
\hline Receiver & $\begin{array}{l}\text { - Can view all post from donor } \\
\text { - Contact with donor } \\
\text { - Collect and distribute the food items }\end{array}$ \\
\hline
\end{tabular}

There are some of the screenshots of our developed website.

\section{Homepage}

The following image is the screenshot of the homepage of developed website. There are four menus in this page; they are home, about, login and signup. Anyone can access the information of this website by clicking on the about menu. Both donor and charity organizations have to be registered using sign up menu. Only the registered users can log into their account using login menu. For this they have to put username and password in the login page. After that the users can provide any kind of information or write the post.

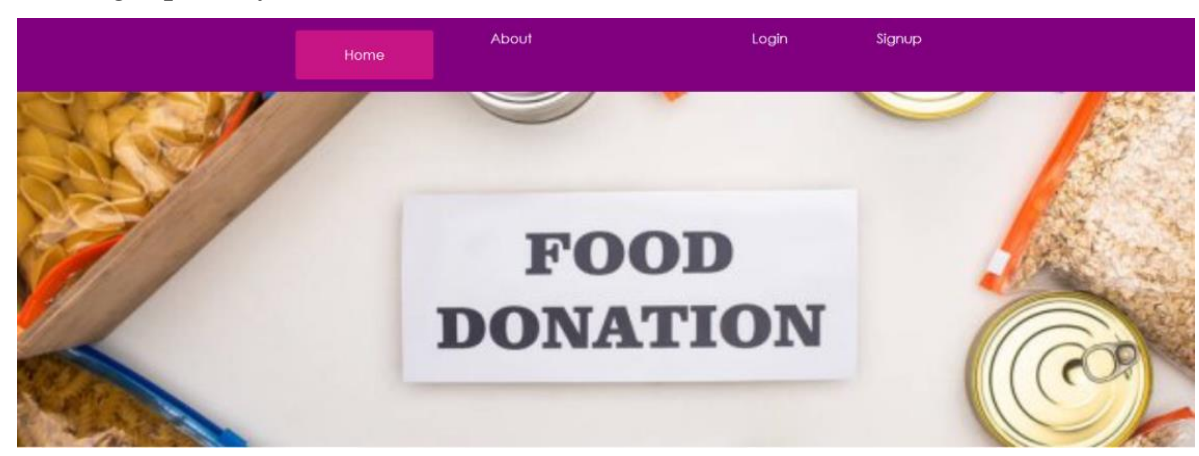

Figure 03: Homepage of the website 


\section{Sign Up}

Donor or restaurant owner or charity owner can register their account by completing a sign up form. The form encouraged to submit about organization name and contact information. When anyone enters into the signup page then they have to put the name of their organization, user name, contact number, email, and password respectively. All information will be updated in the backend database. Once the registration successfully completed the unique username and password provided to all users.

\section{Sign Up}

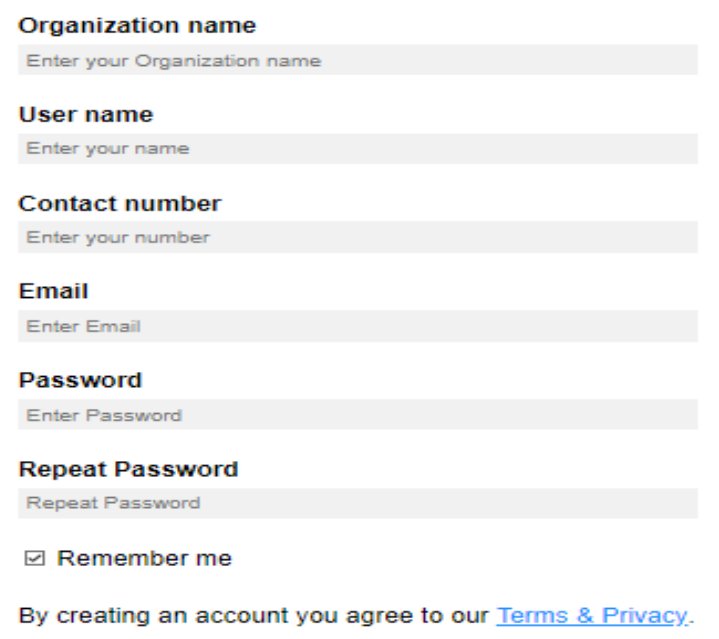

Cancel Sign Up

Figure 04: Registration page for donors

\section{Log in}

If the user has registered already, they can directly login to their account by typing their username and password. Every registered user can logged in to perform any kind of changes to their account. They can also submit post and view all notifications after login using the following page.

\section{Login}

\begin{tabular}{l} 
Email \\
Enter your email \\
Password \\
\hline Enter Password Login \\
\hline
\end{tabular}

Remember me

Figure 05: Login page for donors 


\section{International Journal of Engineering Applied Sciences and Technology, 2021 \\ Vol. 5, Issue 10, ISSN No. 2455-2143, Pages 37-43 \\ Published Online February 2021 in IJEAST (http://www.ijeast.com)}

\section{Publish a Post}

After logging in donor/restaurant owner can submit a post on the following webpage. It allows charity to communicate with owner. For this they have to put the information about item name, quantity, contact number and location respectively.
When the post is published, the post is viewable for everyone. The charity can view the post and contact the donor/restaurant owner by this system and all information will be updated in the database.

\section{Published a post}

\author{
Item name \\ What is your food name? \\ Quantity \\ How much food you have to donate? \\ Contact number \\ Enter your number \\ Location \\ where is your location?
}

\section{Cancel Submit}

Figure 06: Page for publishing the post of food details

\section{View Post}

Only logged in user can able to see the post. They can get the information about food items, quantity, and location as well as contact information of the donor. Only the logged in post publisher can edit his post. Charity organization can view the post and contact with the donor/restaurant owner by this system and all information will be updated in the database.

\begin{tabular}{|c|c|c|c|c|}
\hline Id & Item name & Quantity & Location & Contact \\
\hline 109 & Birani & $\begin{array}{l}24 \\
\text { persons }\end{array}$ & Mirpur & 01700000000 \\
\hline 110 & Rice & 29 plates & Uttara & 01700000011 \\
\hline 111 & Chatpoti & 240 plates & Bonani & 01700000032 \\
\hline 112 & Meat, rice & $\begin{array}{l}50 \\
\text { persons }\end{array}$ & Gulshan & 01700000076 \\
\hline 113 & Polaw & $\begin{array}{l}60 \\
\text { persons }\end{array}$ & $\begin{array}{l}\text { Abdullah } \\
\text { Pur }\end{array}$ & 01700000021 \\
\hline 114 & $\begin{array}{l}\text { Kacchi } \\
\text { Birani }\end{array}$ & 90 plates & Pranthapoth & 01700000088 \\
\hline
\end{tabular}

Figure 07: Page for view the post of all food items

\begin{tabular}{|l|l|}
\hline \multicolumn{2}{|c|}{ List of Software } \\
\hline Operating system & Windows 10 \\
\hline Programming languages & PhP, HTML, CSS \\
\hline Web server & Xamp \\
\hline Database software & My SQL \\
\hline
\end{tabular}

\section{Log Out}

A logout button is terminating the current session for security purpose.

Table 02: Software requirements for developing website

\section{CONCLUSION}

Every day thousands of thousands of food is wasted while many people are starved and suffered from malnutrition. 


\section{International Journal of Engineering Applied Sciences and Technology, 2021 \\ Vol. 5, Issue 10, ISSN No. 2455-2143, Pages 37-43 \\ Published Online February 2021 in IJEAST (http://www.ijeast.com)}

Instead of wasting food, it can be donated to starving people. Many organizations/NGOs/Restaurant can donate their extra food for starving people through the website. This website will be beneficial for diminishing the wastage of food in a country like Bangladesh where 3.4 million street children exist in different cities [18]. In addition, mobile apps can be developed by following this website to rescue food for orphanages. By these systems, our country would be able to reduce food wastage through donation and can rescue food for orphanages and others.

\section{REFERENCE}

[1] https://en.wikipedia.org/wiki/Food_waste\#cite_note2(accessed on August 10, 2020).

[2] https://en.reset.org/knowledge/global-food-waste-and-itsenvironmental-impact-09122018, (accessed on August 17, 2020)

[3] Food loss and Food waste, FAO, http://www.fao.org/foodloss-and-food-waste/en/ (accessed on august 26, 2020)

[4] Jenny Gustavson, Christel Cederberg, Ulf Sonesson, Robert van Otterdijk, Alexandre Meybeck (2011), Global Food Losses and Food Waste (PDF). FAO.

[5] The Daily Star (June 05, 2013). https://www.thedailystar.net/news/waste-not-want-not (accessed on September 17, 2020).

[6] Dhaka tribune (November 30, 2016), https://www.dhakatribune.com/bangladesh/2016/11/30/55-food-wasted-bangladesh(accessed on September 23, 2020).

[7] The financial express (November 14, 2019), https://thefinancialexpress.com.bd/national/most-foodwaste-takes-place-at-wedding-parties-actionaidbangladesh-1573707217(accessed on September 29, 2020).

[8] Suraya Masrom, Abdullah Sani Abd. Rahman, Farah Norliyana Azahar, Nasiroh Omar (2018), Food for You (F4U) Mobile Charity Application, International Journal of Engineering and Technology, Vol 7(4.19), Pg520-523.

[9] https://www.giveindia.org (accessed on October 10, 2020).

[10] https://www.bidyanondo.org/,Web online Available at https://onetakameal.org/food-projects/Feed-the-DestituteOrphans (accessed on October 21,2020).

[11] Naman Talati, Omkar Surve, Jenil Shah, Shrey Kyal (2017), International Journal for Scientific Research \& Development, Vol. 4, Issue 11, Pg491-493

[12] Aron Ciaghi, A Villafiorita (2016) "Beyond food sharing: Supporting food wastage reduction using ICT", IEEE International Smart Cities Conference (ISC2), DOI: https://doi.org/10.1109/ISC2.2016.7580874
[13] Divyesh Jethwa, Ayushi Agrawal, Rohan Kulkarni, LeenaRaut (2018), "Food Wastage Reduction Through Donation, International Journal of Recent Trends in Engineering \& Research, Volume 04, Issue 03, Pg681686.

[14] R. Adline Freeda, M.S.SahlinAhamed (2018), Mobile Application for Excess Food Donation and Analysis" International Journal of Innovative Research in Science, Engineering and Technology, Vol 7, Issue 04, Pg60-63.

[15] Đeni Lovrenčić Nenad Vretenar Zoran Ježić (2017), The Challenges of Establishing Food Donation System, International Scientific Conference on IT, Tourism, Economics, Management and Agriculture, Budapest, Hungary, Pg622-629

[16] Md. Touhidul Alam Khan and Raisa Rahim_(2013), https://www.thedailystar.net/news/waste-not-want-not (accessed on February 26, 2021).

[17] Whats.com (November 2006) https://whatis.techtarget.com/definition/PHP-HypertextPreprocessor (accessed on December 11, 2020).

[18] the independent (February 6, 2016), http://www.theindependentbd.com/printversion/details/329 32 (accessed on December 16 ,2020). 